in vivo $34: 1729-1738(2020)$

doi:10.21873/invivo.11966

\title{
Biological Properties of the Aggregated Form of Chitosan Magnetic Nanoparticle
}

\author{
ANGEL DAVID PAULINO-GONZALEZ ${ }^{1,2}$, HIROSHI SAKAGAMI ${ }^{3}$, KENJIRO BANDOW $^{3}$, \\ YUMIKO KANDA $^{3}$, YUKO NAGASAWA ${ }^{3}$, YASUSHI HIBINO ${ }^{3}$, HIROSHI NAKAJIMA $^{3}$, SATOSHI YOKOSE $^{3}$, \\ OSAMU AMANO ${ }^{3}$, GIICHIROU NAKAYA ${ }^{4}$, YUKARI KOGA-OGAWA ${ }^{4}$, AKIYOSHI SHIROTO ${ }^{4}$, \\ TADAMASA NOBESAWA ${ }^{4}$, DAISUKE UEDA ${ }^{4}$, SACHIE NAKATANI $^{5}$, KENJI KOBATA ${ }^{5}$, YOSUKE IIJIMA ${ }^{6}$, \\ SHINSUKE IFUKU $^{7}$, MASAJI YAMAMOTO ${ }^{8}$ and RENE GARCIA-CONTRERAS ${ }^{1}$ \\ ${ }^{1}$ Laboratorio de Investigación Interdisciplinaria, Área de Nanoestructuras y Biomateriales, \\ Escuela Nacional de Estudios Superiores Unidad León, León, México; \\ ${ }^{2}$ Dental Science, National Autonomous University of Mexico, Mexico City, Mexico; \\ ${ }^{3}$ Meikai University School of Dentistry, Saitama, Japan; \\ ${ }^{4}$ Nihon Institute of Medical Science Faculty of Health Sciences, Saitama, Japan; \\ ${ }^{5}$ Graduate School of Pharmaceutical Sciences, Josai University, Saitama, Japan; \\ ${ }^{6}$ Saitama Medical Center, Saitama Medical University, Saitama, Japan; \\ ${ }^{7}$ Department of Veterinary Clinical Medicine, Tottori University, Tottori, Japan; \\ ${ }^{8}$ Koyo Chemical Co. Ltd., Tokyo, Japan
}

\begin{abstract}
Background/Aim: Chitosan-coated iron oxide nanoparticles (Chi-NP) have gained attention because of their biocompatibility, biodegradability, low toxicity and targetability under magnetic field. In this study, we investigated various biological properties of Chi-NP. Materials and Methods: Chi$N P$ was prepared by mixing magnetic NP with chitosan FL-80. Particle size was determined by scanning and transmission electron microscopes, cell viability by MTT assay, cell cycle distribution by cell sorter, synergism with anticancer drugs by combination index, $P G E_{2}$ production in human gingival fibroblast was assayed by ELISA. Results: The synthetic process of Chi-NP from FL-80 and magnetic NP increased the affinity to cells, up to the level attained by nanofibers. Upon contact with the culture medium, Chi-NP instantly formed aggregates and interfered with intracellular uptake. Aggregated Chi-NP did not show cytotoxicity, synergism with
\end{abstract}

This article is freely accessible online.

Correspondence to: Hiroshi Sakagami, Meikai University Research Institute of Odontology, 1-1 Keyakidai, Sakado, Saitama 350-0283, Japan. Tel: +81 492792758, e-mail: sakagami@dent.meikai.ac.jp; Rene Garcia-Contreras, Boulevard UNAM \#2011, Col. Predio El Saucillo y El Potrero 37689 San Antonio de los Tepetates, León, Guanajuato, México. Tel: +52 4771940800 ext. 43463, e-mail: dentist.garcia@gmail.com

Key Words: Chitosan, magnetic nanoparticle, affinity, uptake, cytotoxicity, inflammation, X-ray sensitivity. anticancer drugs, induce apoptosis (accumulation of subG1 cell population), protect the cells from $X$-ray-induced damage, nor affected both basal and IL-1 $\beta$-induced $P G E_{2}$ production. Conclusion: Chi-NP is biologically inert and shows high affinity to cells, further confirming its superiority as a scaffold for drug delivery.

Nanotechnology is applied to diverse fields of science. Especially, iron oxide nanoparticles (NP) are promising magnetic materials. Their biological behavior is greatly affected by the method of preparation, shape, size and coating method. Chitosan is a partially deacetylated product of chitin [poly $(\beta-(1 \rightarrow 4)-N$-acetyl-D-glucosamine present in the exoskeleton of arthropods or in the cell walls of fungi and yeast], and is recognized as a good material for coating NP (1). Chitosan is used for the regeneration of functional dental pulp (2), osteogenesis (3), modification and improvement of existing dental materials (4) and drug delivery and tissue engineering (5). Due to its cationic property, biodegradability, antibacterial activity and interaction with other molecules, chitosan nanoparticles have been used for the study of drug delivery and scaffold (6-11).

Chitosan-coated magnet nanoparticles (Chi-NP) have gained attention because of their biocompatibility, biodegradability, low toxicity and targetability under magnetic field $(6,12-14)$. In order to use Chi-NP clinically, the lesser the biological activity they show, the better. Therefore, we have investigated whether Chi-NP synthesized in the laboratory is biologically inert or not. We also established a method that allows us to 


\section{Method 1}

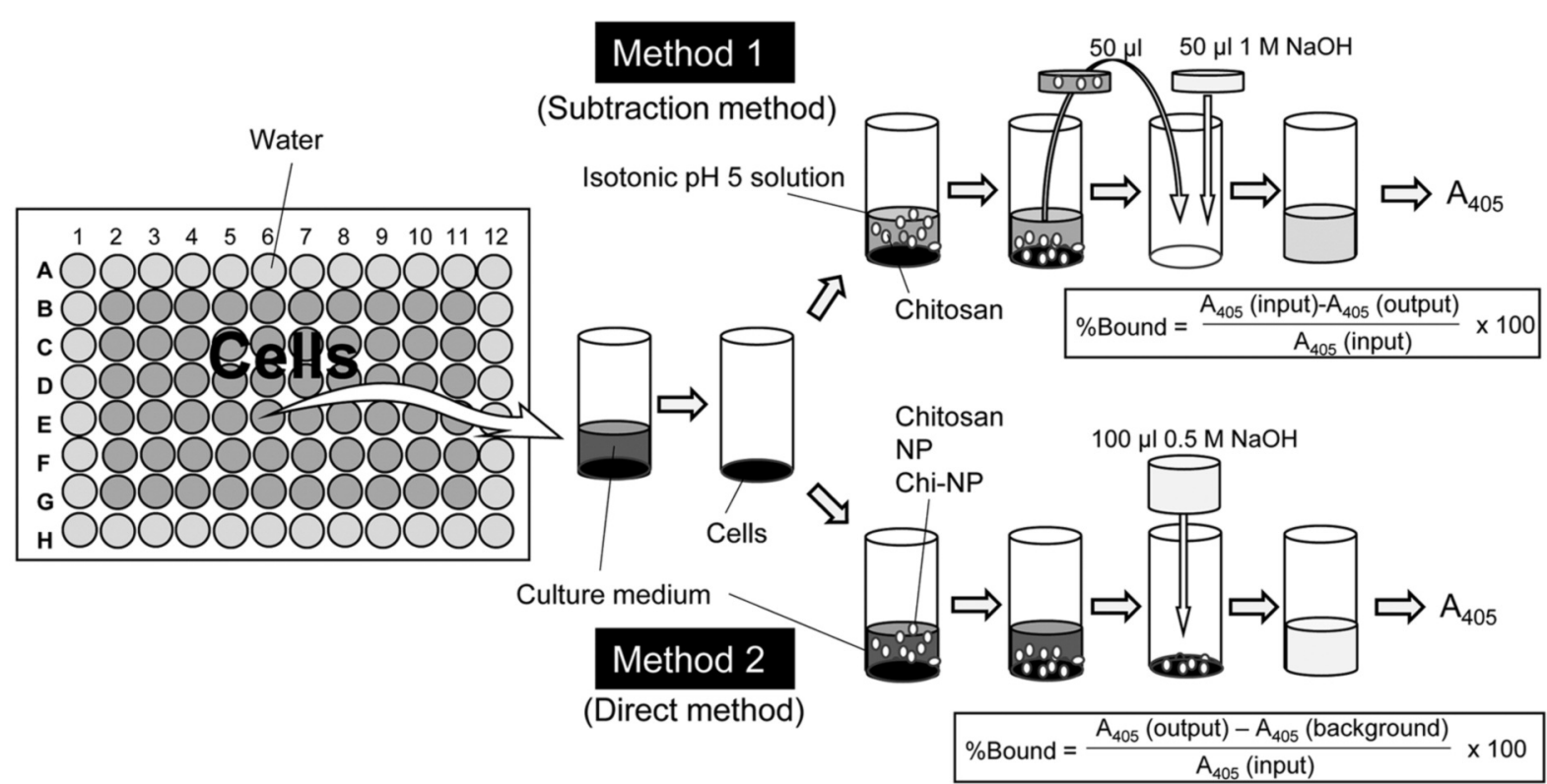

(Subtraction method)

Isotonic $\mathrm{pH} 5$ solution
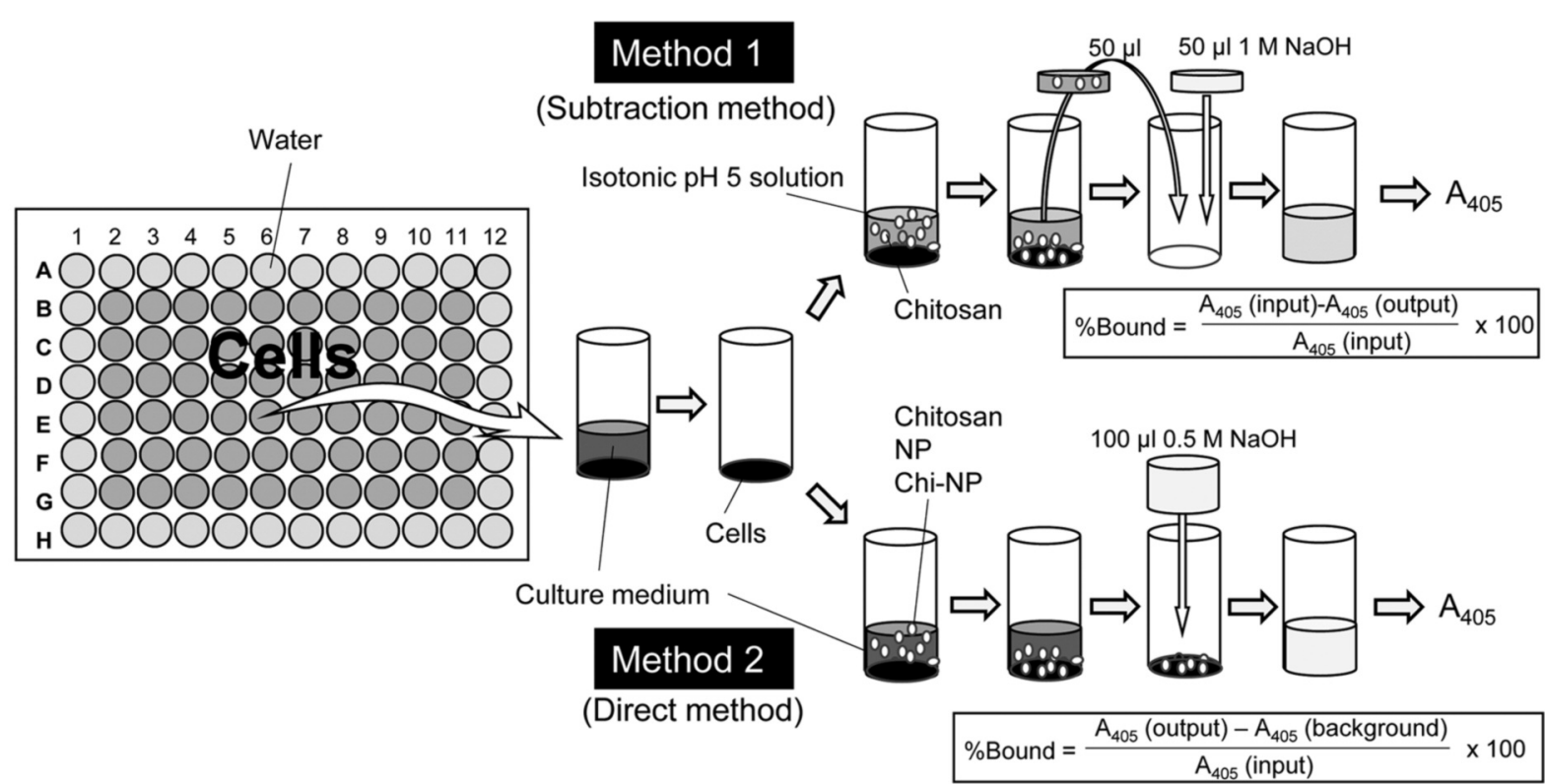

$50 \mu 11 \mathrm{M} \mathrm{NaOH}$

Figure 1. Two methods that explain how to calculate the cell-bound amount of chitosan, NP and Chi-NP. Method 1, Subtraction method: Cell-bound amount $(\%)=\left(\right.$ Input $A_{405}$-Output $\left.A_{405}\right) /$ Input $A_{405}$. Method 2, Direct method: Cell-bound amount $(\%)=$ Recovered $A_{405} /$ Initial $A_{405}$. $A_{405}$ represents absorbance at $405 \mathrm{~nm}$.

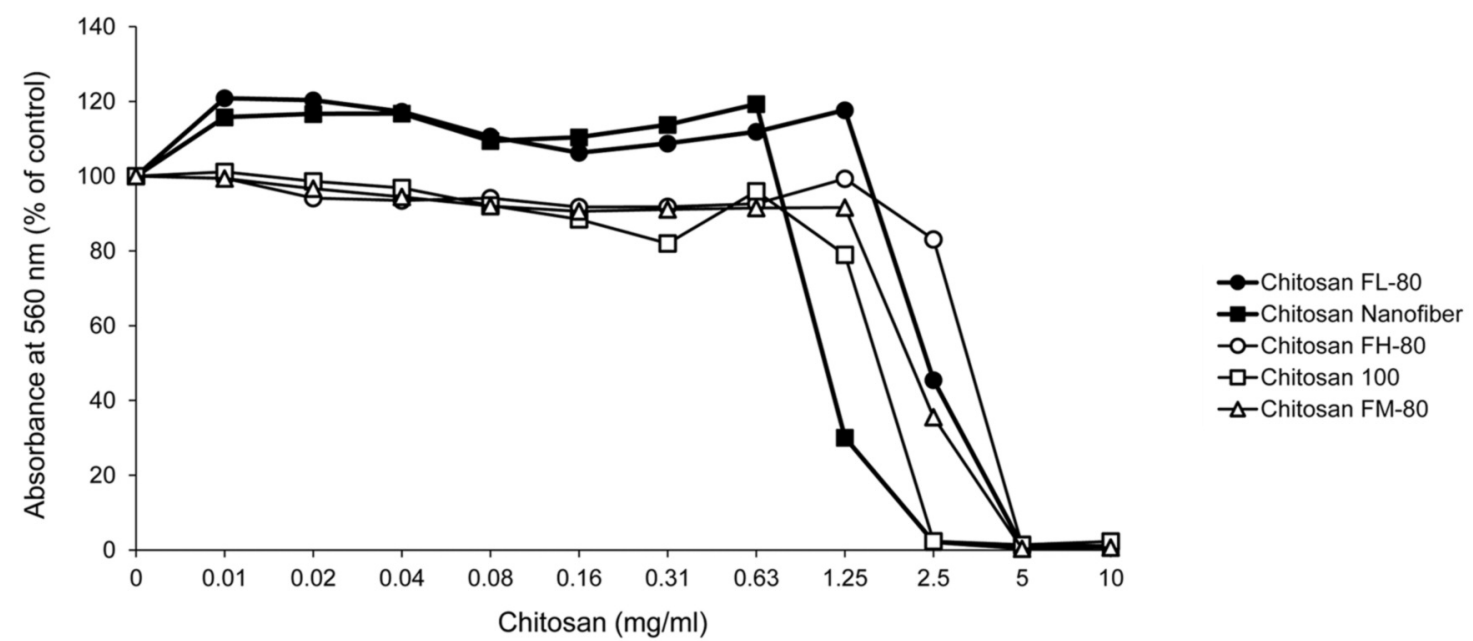

Figure 2. Cytotoxicity of 5 chitosan samples against HSC-2 cells. HSC-2 cells were incubated for $48 \mathrm{~h}$ with the indicated concentrations of chitosan nanofiber $(\square)$ or chitosan $[F L-80(\bullet), F H-80(\bigcirc), 100(\square)$ or FM-80 ( $\triangle)]$, and then viable cell numbers were determined by the MTT method. Each value represents mean \pm S.D. of triplicate assays.

compare the affinity (or binding) to the plates and cells between Chi-NP, chitosan and NP.

\section{Materials and Methods}

Reagents. The following reagents were obtained from the companies indicated in the parentheses: Four chitosan samples (FH-80,100, FM-80, FL-80) (grade of deacetylation was $>80 \%$ )
(Koyo chemical CO.LTD, Tokyo, Japan), chitosan marine nanofiber (provided at $10 \mathrm{mg} / \mathrm{ml}$ in $0.5 \%$ acetic acid by $\mathrm{Dr}$. Shinsuke Ifuku, Department of Veterinary Clinical Medicine, Tottori University); acetic acid ( $>97 \%$ of purity), ferric chloride hexahydrate $\left(\mathrm{FeCl}_{3} \cdot 6 \mathrm{H}_{2} \mathrm{O}\right)$, ferrous chloride tetrahydrate $\left(\mathrm{FeCl}_{2} \cdot 4 \mathrm{H}_{2} \mathrm{O}\right)$, ammonium hydroxide, dimethyl sulfoxide (DMSO) (FUJIFILM Wako Pure Chemical Corporation, Osaka, Japan), Dulbecco's modified Eagle's medium (DMEM) (Gibco BRL, Grand Island, NY, USA), fetal bovine serum (FBS), 3-(4,5- 
A
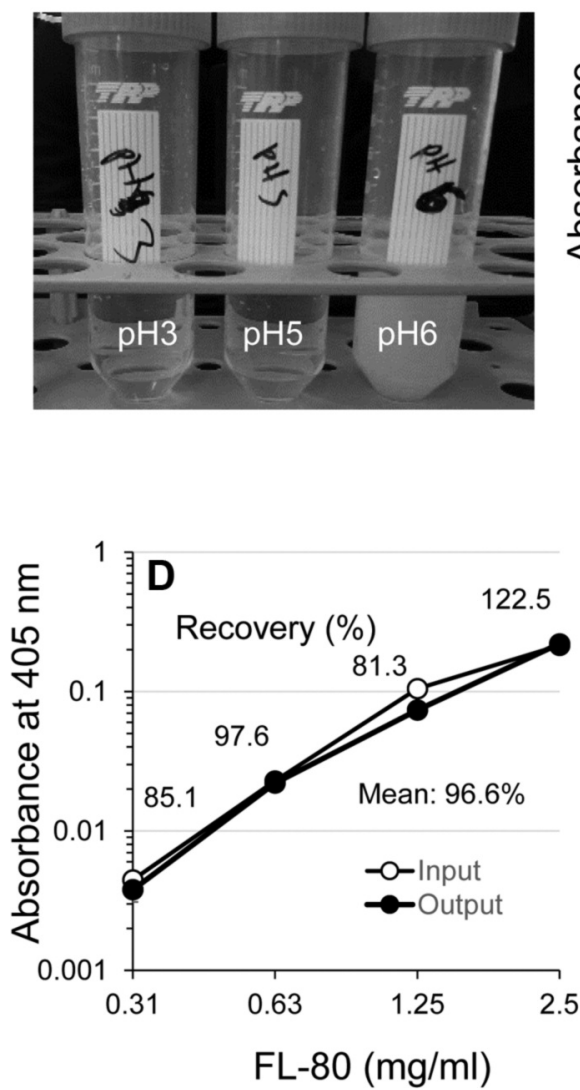
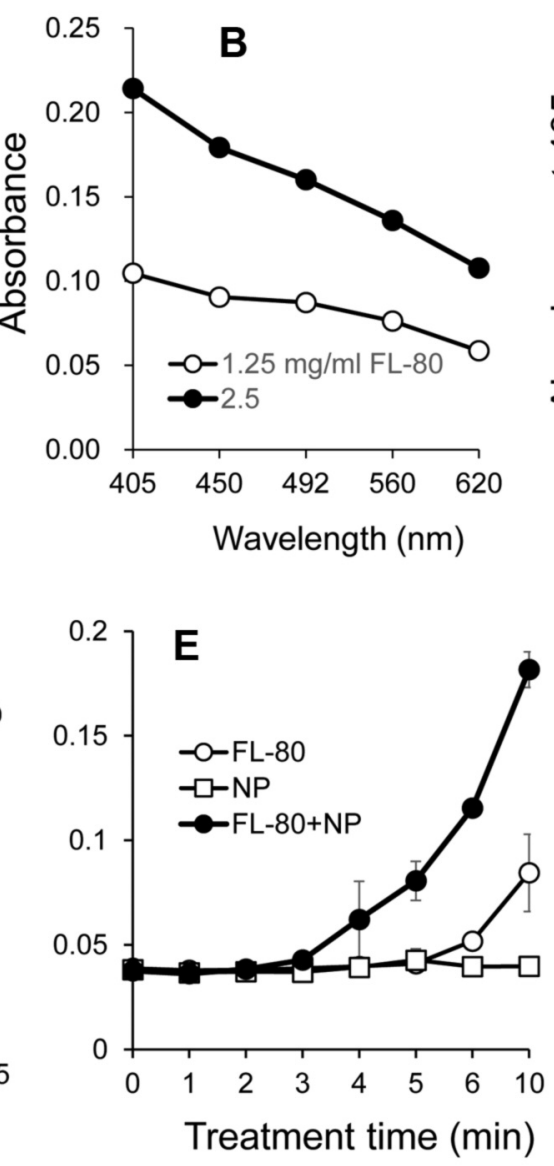
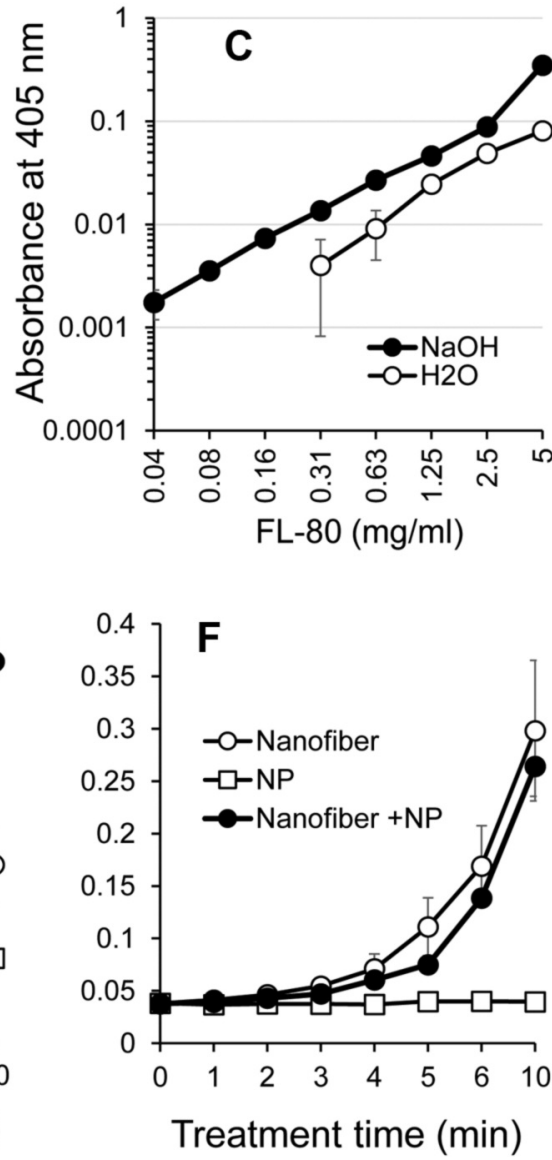

Figure 3. Properties of chitosan. (A) Solubility of chitosan in isotonic buffer adjusted at pH 3, pH 5 or pH 6 . (B) Absorbance intensity of FL-80 [1.25 (०) and $2.5(\bullet) \mathrm{mg} / \mathrm{ml}$ ] at different wavelengths. (C) Log scale plot of absorbance intensity of chitosan FL-80 at different concentrations in $\mathrm{H}_{2} \mathrm{O}(\mathrm{O})$ and $0.5 \mathrm{M} \mathrm{NaOH}(\bullet)$ solution. Each value represents the mean value $\pm S . D(n=6)$. (D) Calculation of cell-bound FL-60 by the subtraction method (Method 1) Absorbance of FL-80 initially added to HSC-2 cells (input) (O) and after it was recovered from the culture supernatant (output)

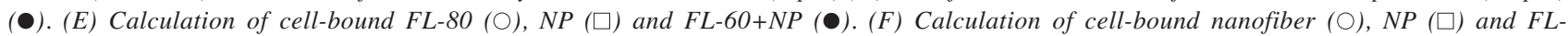
$60+$ nanofiber $+N P(\bullet)$. Each value represents mean \pm S.D. $(n=6)$.

dimethylthiazol-2-yl)-2,5-diphenyltetrazolium bromide (MTT) (Sigma-Aldrich Inc., St. Louis, MO, USA), culture plastic dishes and 96-well plates from Techno Plastic Products AG (Trasadingen, Switzerland).

Adjustment of osmolarity of chitosan solution. Isotonic sodium citrate buffer ( $\mathrm{pH}$ 3.0), sodium acetate buffer ( $\mathrm{pH}$ 5.0) and phosphate buffer ( $\mathrm{pH} 6.0$ ) were prepared by adjusting the osmolarity to $290 \mathrm{mOsm}$ by adding pure water, using an osmometer (Gonotec $\mathrm{GmbH}$, Berlin, Germany).

Preparation of Chitosan-magnetic nanoparticles. $\mathrm{FeCl}_{3} \cdot 6 \mathrm{H}_{2} \mathrm{O}(1.6$ g) and $\mathrm{FeCl}_{2} \cdot 4 \mathrm{H}_{2} \mathrm{O}(0.9 \mathrm{~g})$ were placed in a beaker, and deionized water $(40 \mathrm{ml})$ was added, kept under magnetic stirring for $10 \mathrm{~min}$, and then precipitated by drip addition of $\mathrm{NH}_{4} \mathrm{OH}(5 \mathrm{ml})$. The precipitate was separated with a magnet and washed 3 times with deionized water to remove ammonium hydroxide and dried up at $40^{\circ} \mathrm{C}$ in the oven. Then, nanoparticles thus obtained $(300 \mathrm{mg})$ were added to the chitosan solution (5 mg of chitosan FL-80 dissolved in
$25 \mathrm{ml}$ of $0.5 \%$ acetic acid) and kept overnight under shaking at $25^{\circ} \mathrm{C}$, accompanied by the change in the color of the solution from black to brown. Chitosan-magnetic nanoparticles were washed with water, and then dried up as described above.

Characterization of chitosan samples and Chi-NP. Before the addition of medium, the particle size, distribution and morphology of chitosan was evaluated by scanning electron microscope (SEM) [JSM-6360, Japan Electron Optics Laboratory (JEOL) Co. Ltd. Akishima, Tokyo, Japan] (magnification: $\times 200$ ) at an accelerating voltage of $20 \mathrm{kV}$, and those of Chi-NP were evaluated by SEM and transmission electron microscope (TEM) (JEM-1210, JEOL Co. Ltd.) (magnification: $\times 5,000)$ at an accelerating voltage of $100 \mathrm{kV}$.

Assay for cytotoxic activity. Human oral squamous cell carcinoma lines (Ca9-22, HSC-2, HSC-3, HSC-4) and human normal oral cells [gingival fibroblast (HGF), periodontal ligament fibroblast (HPLF), pulp cell (HPC)] were cultured at $37^{\circ} \mathrm{C}$ in DMEM supplemented with $10 \%$ heat-inactivated FBS under a humidified atmosphere with 

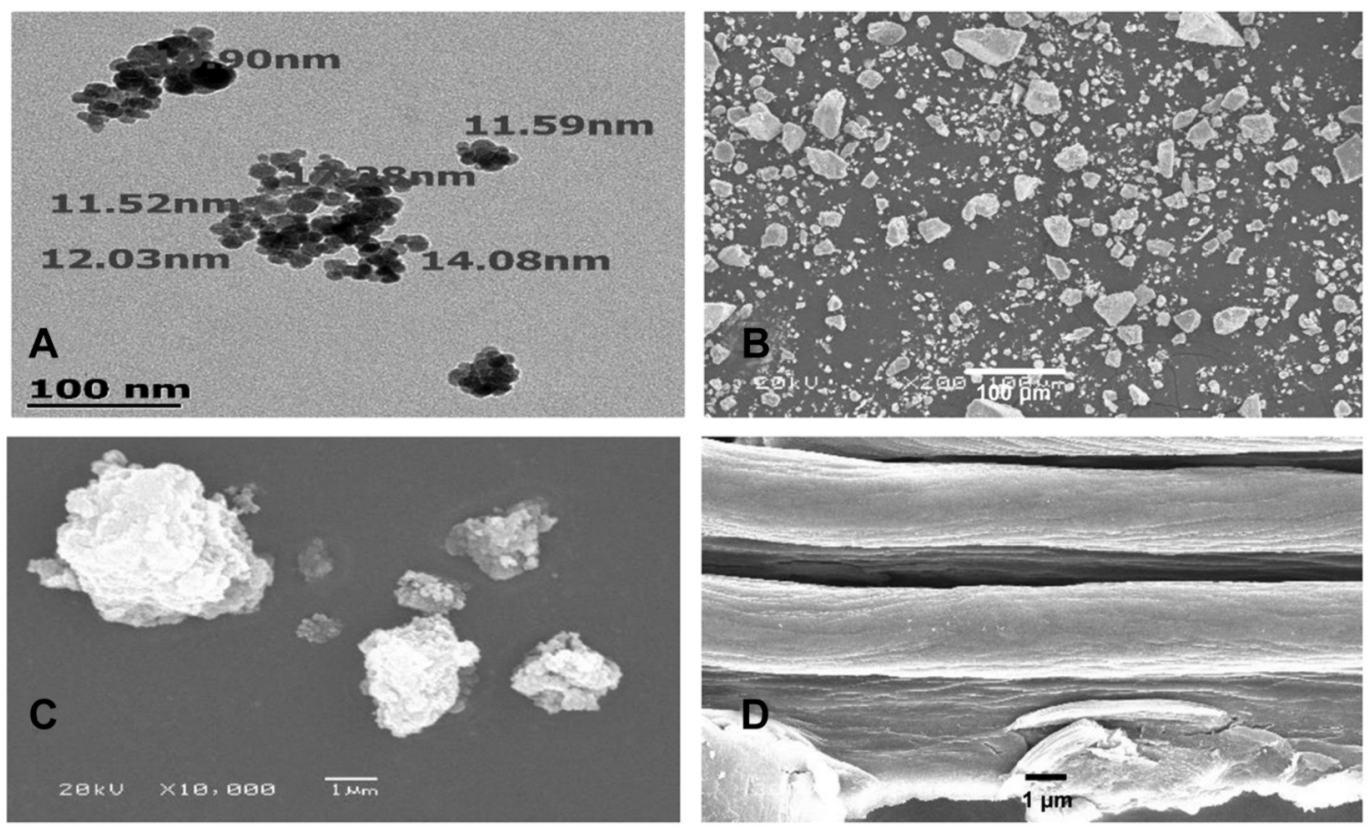

Figure 4. (A) TEM analysis before chitosan addition. SEM analysis of the magnetic nanoparticles encapsulated by chitosan-coating (B, C) and chitosan nanofibers $(D)$.

$5 \% \mathrm{CO}_{2}$. To achieve complete cell attachment, cells were inoculated at $2 \times 10^{3}$ cells/well in a 96-microwell plate and cultured for $48 \mathrm{~h}$, unless otherwise stated. Attached cells were incubated for a further $48 \mathrm{~h}$ in fresh medium containing various concentrations of the test samples to determine the relative viable cell number in triplicate by the MTT method, as described previously (15).

Binding kinetics to the plates and cells. We newly explored the following two methods for measuring the binding strength of chitosan, magnetic NP and (Chi-NP to the cells (Figure 1). (Method 1: subtraction method) HSC-2 cells were incubated for $0 \sim 10 \mathrm{sec}$ with $100 \mu \mathrm{l}$ of isotonic $\mathrm{pH} 5$ solution that contains various concentrations of chitosan, and then $50 \mu \mathrm{l}$ aliquots of the supernatant were taken at the indicated times and mixed with $50 \mu \mathrm{l}$ $1 \mathrm{M} \mathrm{NaOH}$ to induce precipitation and the absorbance was measured at $560 \mathrm{~nm}$. The percent of cell-bound chitosan was determined by the following equation: $\%$ Bound $=\left\{\left[\mathrm{A}_{405}\right.\right.$ (input) $-\mathrm{A}_{405}$ (output)] $/ \mathrm{A}_{405}$ (input) $\} \times 100$. (Method 2: direct method) HGFs were incubated for $0 \sim 10 \mathrm{~min}$ with $100 \mu \mathrm{l}$ of fresh culture medium (DMEM+10\%FBS) containing various concentrations of chitosan, NP and Chi-NP. At the indicated times thereafter, the medium was completely removed by suction and $100 \mu \mathrm{l} 0.5 \mathrm{M} \mathrm{NaOH}$ was added and the absorbance was measured at $405 \mathrm{~nm}$. The percent of cellbound chitosan was determined by the following equation: $\%$ Bound $=\left\{\left[\mathrm{A}_{405}\right.\right.$ (Output) $-\mathrm{A}_{405}$ (background) $] / \mathrm{A}_{405}$ (input) $\} \times 100$.

Intracellular uptake of Chi-NP. Near confluent HGFs, HPLFs and HPCs were treated with 2 or $10 \mathrm{mg} / \mathrm{ml} \mathrm{Chi-NP}$ for $3 \mathrm{~h}$. After washing three times with PBS (-), cells were fixed for $1 \mathrm{~h}$ with $2 \%$ glutaraldehyde in $0.1 \mathrm{M}$ cacodylate buffer $(\mathrm{pH} 7.4)$ at $4^{\circ} \mathrm{C}$. The cells were collected by scraping with a rubber policeman, post-fixed, dehydrated and embedded in Araldite M, stained with uranyl acetate and lead citrate, and then observed under a JEM-1210 transmission electron microscope, as described previously (16).

Calculation of the combination index. Near confluent cells were incubated in fresh medium containing the indicated concentrations of Chi-NP and anticancer drug (5-FU, abraxane or cisplatine) for $48 \mathrm{~h}$ to determine the viable cell number by the MTT method. The combination index (CI) value was determined by the following equation: $\mathrm{CI}=(\%$ decrease of viable cell number by compound $\mathrm{A}+\%$ decrease of viable cell number by compound $\mathrm{B}) /(\%$ decrease of viable cell number by combination of compound A and B). The combination effect was evaluated as "synergistic", "additive" or "antagonistic" when CI was $<1,1$ and $>1$, respectively (17).

Cell-cycle analysis. Cells (approximately $10^{6}$ cells) grown in 100 $\mathrm{mm}$ dishes were harvested by trypsinization, fixed, treated with ribonuclease A, stained with propidium iodide, filtered through cell strainer to remove the aggregated cells and debris and then subjected to cell-cycle analysis with Cell Sorter Software version 2.1.2. (SONY Imaging Products and Solution Inc., Tokyo, Japan), as described previously (15).

Pro-inflammation assay. Near confluent HGFs were treated for $48 \mathrm{~h}$ with of NP $(0,0.31 .0 .62$ and $1.25 \mathrm{mg} / \mathrm{ml})$, in the presence or absence of IL-1 $\beta(3 \mathrm{ng} / \mathrm{ml})$. Then, the concentration of $\mathrm{PGE}_{2}$ released into the culture supernatant was determined by ELISA, according to manufacturer's instruction (Cayman, Ann Arbor, MI, USA).

X-Ray irradiation: X-Ray irradiation was performed using a diagnostic X-ray apparatus (UD150L-30W, SHIMAZU, Kyoto, 


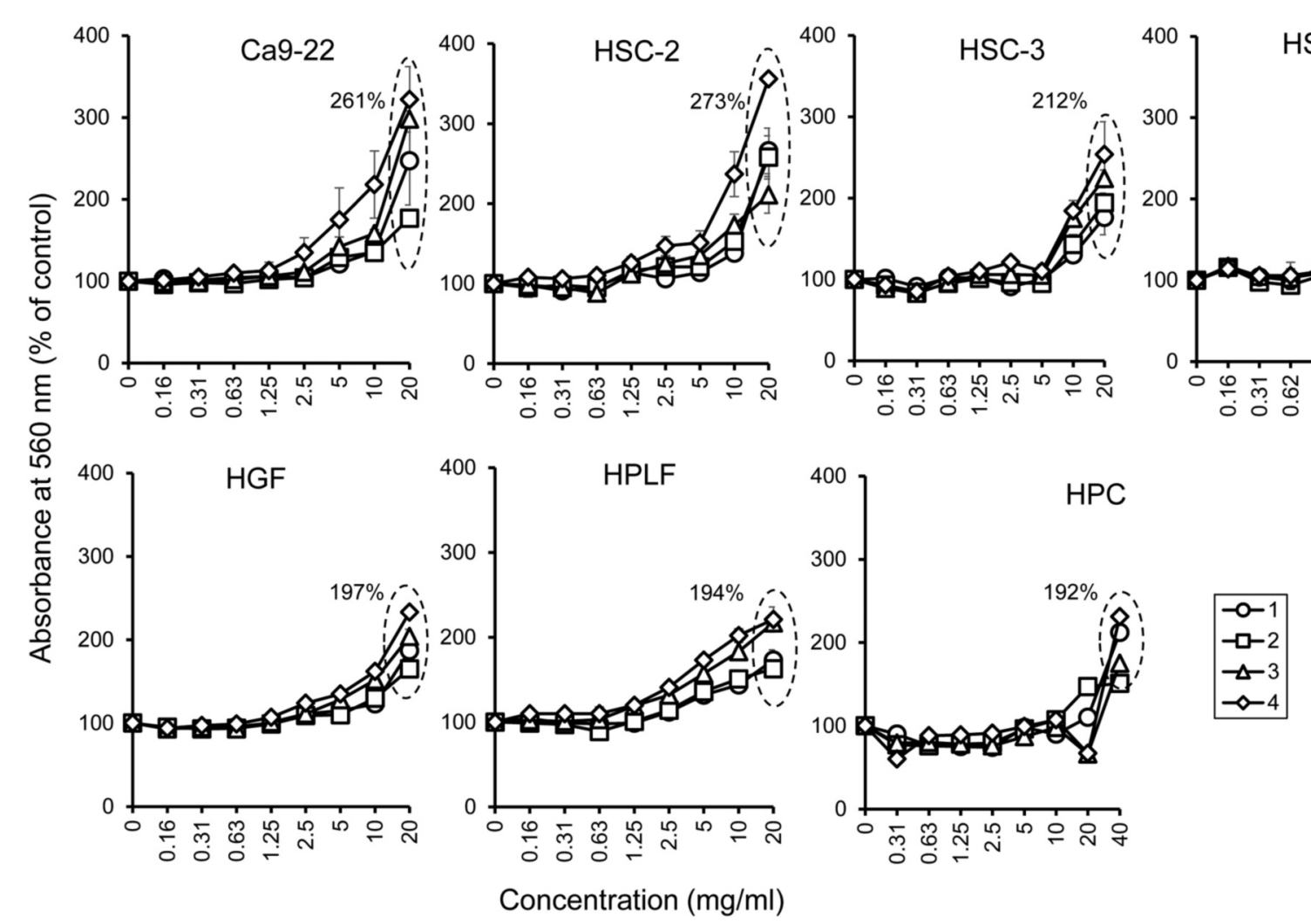

Figure 5. Effect of chitosan magnetic nanoparticles on the growth of human malignant and non-malignant cells. Human oral squamous cell carcinoma cell lines (Ca9-22, HSC-2, HSC-3, HSC-4) and three human normal oral cells [HGF (gingival fibroblasts), HPLF (periodontal ligament fibroblasts), HPC (pulp cells)] were incubated for $48 \mathrm{~h}$ with the following four lots of chitosan magnetic nanoparticles: $1=$ nanoparticles $+5 \mathrm{mg}$ chitosan $+0.5 \%$ acetic acid with 5 stirring $h .2=$ nanoparticles $+5 \mathrm{mg}$ chitosan $+0.5 \%$ acetic acid with overnight stirring. $3=$ nanoparticles $+5 \mathrm{mg}$ chitosan $+1 \%$ acetic acid with 5 stirring h. 4=nanoparticles $+5 \mathrm{mg}$ chitosan $+1 \%$ acetic acid with overnight stirring. Each value represents means of 6 determinations.

Japan). The 96-well plates that contain cells were placed at the cathode side of an X-ray tube (SHIMAZU, P38DE 80s) on acrylic plate ( $4 \mathrm{~cm}$ high) and irradiated at 0 or $900 \mathrm{mGy}$ (0- or 32-times Xray irradiation for $0.2 \mathrm{sec}$ at $200 \mathrm{~mA}$ and $100 \mathrm{kV}$ ). The dose of the $\mathrm{X}$-ray absorbed by the cells was corrected by multiplying the value obtained by skin exposure dosimeter with the correction factor, as described previously (18).

\section{Results}

Properties of nanofibers and chitosan: Among five chitosan samples, FL-80 and chitosan nanofiber supported well the growth of HSC-2 cells at lower concentrations (0.01 0.63 $\mathrm{mg} / \mathrm{ml}$ ), whereas chitosan FH-80, 100 and FM-80 slightly reduced their growth (Figure 2).

Chitosan FL-80 was completely dissolved in the isotonic buffer, $\mathrm{pH} 3$ or 5 , whereas it is was not dissolved well, but rather precipitated in isotonic buffer, $\mathrm{pH} 6$ (Figure 3A). The absorbance of FL-80 was maximum at $405 \mathrm{~nm}$ (Figure 3B). The addition of $\mathrm{NaOH}$ solution resulted in immediate precipitation of FL-80, but the precipitate formation reproducibly increased the absorbance of chitosan (Figure 3C). Due to this unexpected finding, chitosan binding to the cells was determined after the enhancement of sensitivity of the colorimetric determination by alkaline precipitation of chitosan. Linearity of the absorbance of FL-80 was kept between 0.04 to $5 \mathrm{mg} / \mathrm{ml}$ (Figure 3C). When HSC-2 cells were loaded with FL-80, $96.6 \%$ of the initially added was recovered from the cells after $5 \mathrm{sec}$, indicating that the binding of FL-80 to the cells was negligible (Figure 3D). Such a short exposure time was used due to the cytotoxicity of the acidic sample.

Cells were incubated for longer periods of time with the test samples in regular culture medium (DMEM+10\%FBS). In order to reduce the size of aggregated samples, they were sonicated for $30 \mathrm{sec}$ and immediately added to the cells. Results showed that when treatment time was increased to 10 min, FL-80-NP, but not NP, slightly attached to the cells (Figure 3E). However, both chitosan nanofiber and chitosan nanofiber-NP showed much higher affinity to the cells (Figure 3F). 

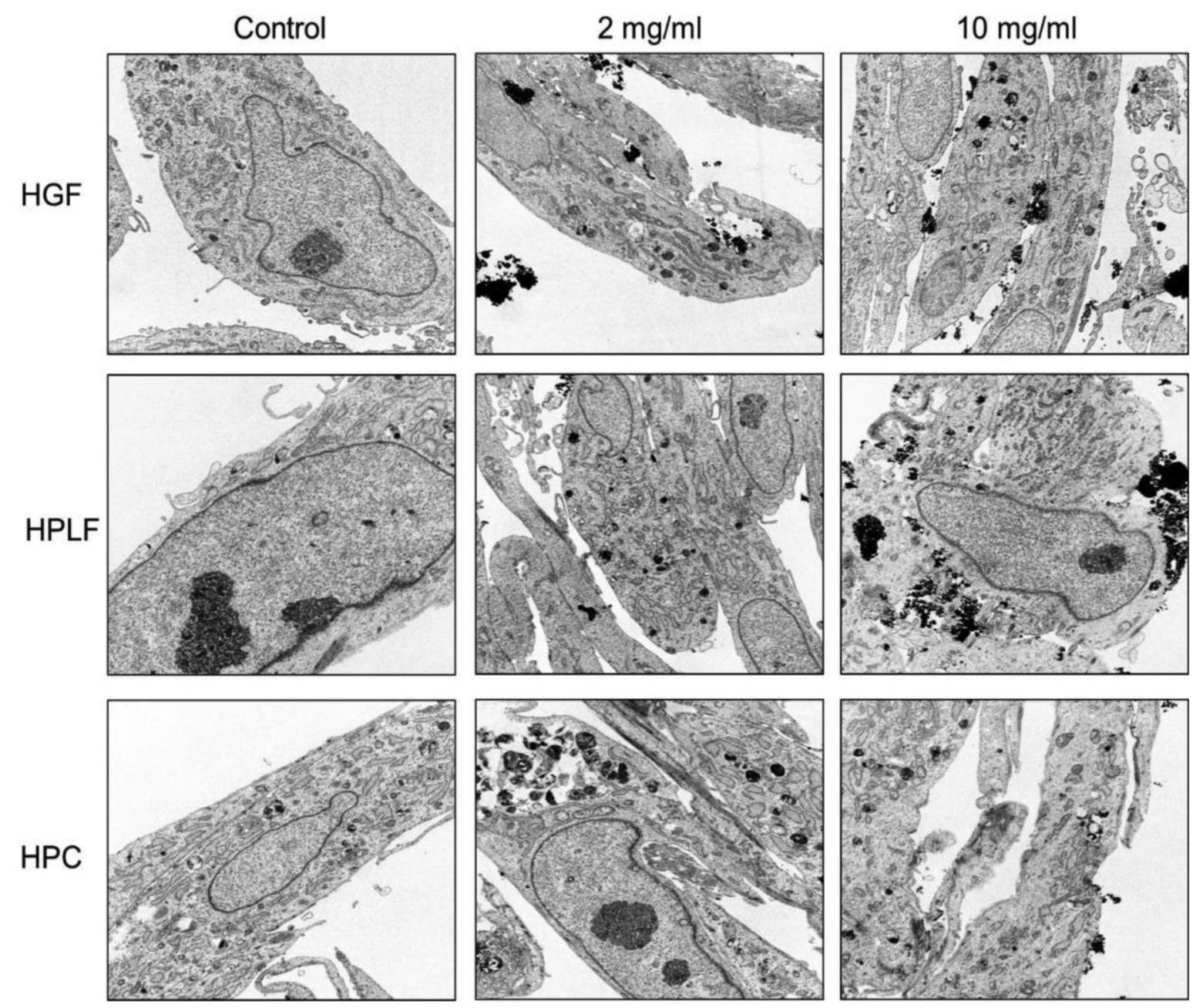

Figure 6. TEM analysis of the intracellular fine structure of HGFs, HPLFs and HPCs after 3 h contact to Chi-NP (chitosan LH-80-Fe $\mathrm{O}_{4}$ nanoparticle) (2 and $10 \mathrm{mg} / \mathrm{ml}$ ). The formation of clusters in the cytoplasm and around the membrane prevents the internalization of Chi-NP.

Characterization of NP and chi-NP. TEM analysis demonstrated that the average size of the synthesized magnetic nanoparticle (NP) before addition of FL- 80 was $30 \pm 5 \mathrm{~nm}$ with a semi-spherical morphology, showing some tendency to aggregate (Figure 4A). SEM demonstrated that the encapsulation of magnetic nanoparticles by FL-80 (Chi-NP) changed the size, shape and cell-NP interaction considerably $(\mathrm{B}, \mathrm{C})$, in contrast to chitosan nanofiber that has well-defined linear patterns of surface morphology (D) (Figure 4).

Cytotoxicity assay. The cytotoxicity of chitosan-nanoparticle (Chi-NP) prepared under four different conditions was investigated. All four samples showed similar dose-response curves against four human oral squamous cell carcinoma cell lines (Ca9-22, HSC-2, HSC-3, HSC-4) and three normal oral cells (HGF, HPLF, HPC). At lower concentrations $(0.16 \sim 0.31 \mathrm{mg} / \mathrm{ml})$, cell proliferation was not apparently affected. However, at higher concentrations (1.25 40 $\mathrm{mg} / \mathrm{ml}$ ), the absorbance of MTT-stained cells began to increase, up to nearly two-fold of the control (Figure 5). This abrupt increase in absorbance does not reflect the increase in the cell number, but rather the attachment of Chi-NP to the cells. Observation under TEM demonstrated that Chi-NP at 2 or $10 \mathrm{mg} / \mathrm{ml}$ induced no apparent alterations in the intracellular architecture and integrity of intracellular organelles, without any discernible intracellular uptake of aggregated Chi-NP (Figure 6).

Combination effect with anticancer drugs. Three popular anticancer drugs, 5-FU, abraxane and cisplatin, dosedependently reduced the viable cell number of HSC-2 cells (black circle, Exp. I and II, Figure 7), confirming our previous finding (15). We next investigated the combination effect of these anticancer drugs and Chi-NP (0.08 1.25 mg/ml). Chi- 

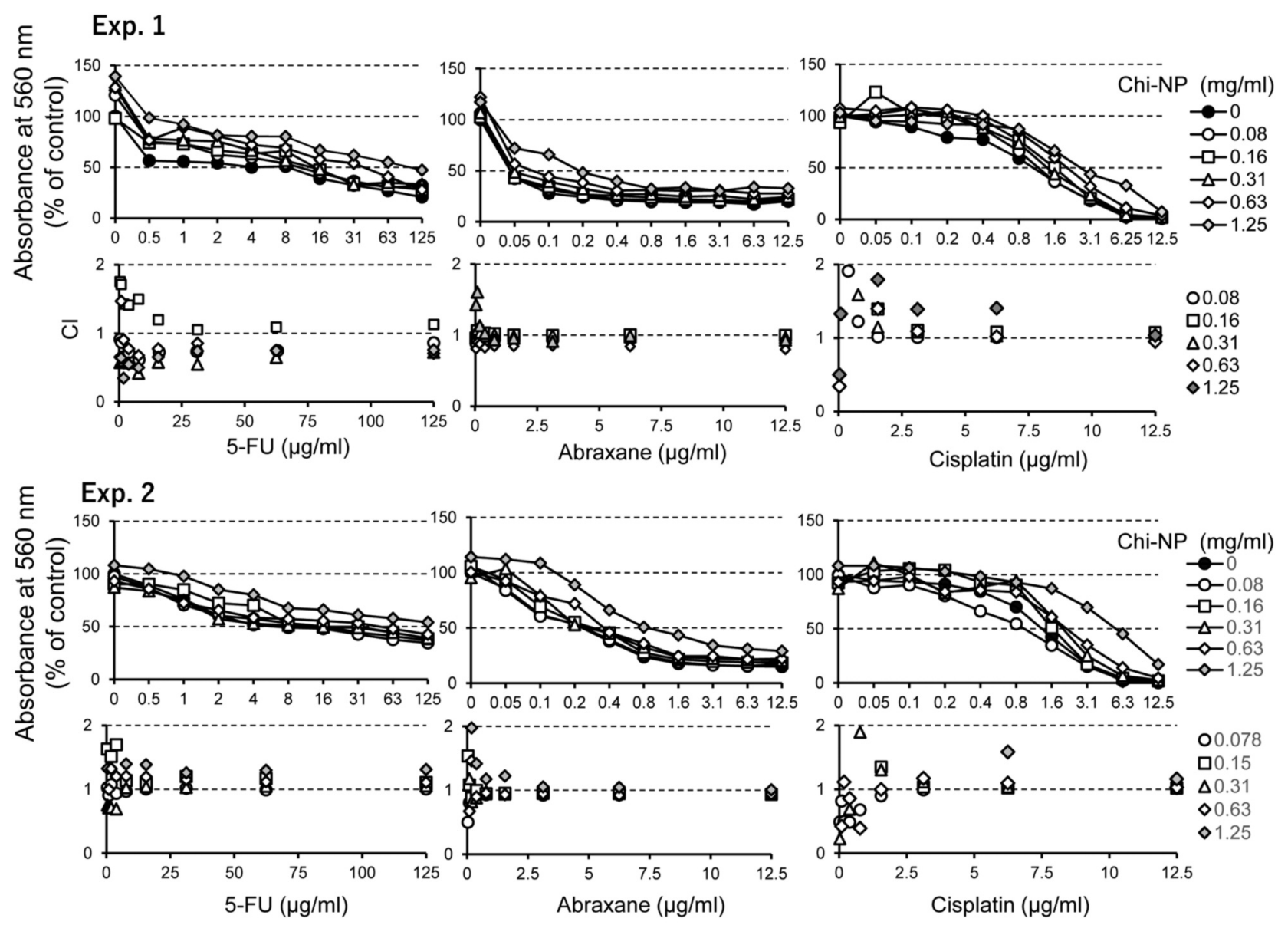

00.08

$\square 0.16$

$\Delta 0.31$

$\diamond 0.63$

$\diamond 1.25$

Figure 7. The combination effect of nanoparticles and popular anticancer drugs. a) Effect of 5-FU, abraxane and cisplatin on the viable cell number of HSC-2 cells. Near-confluent HSC-2 cells were incubated for $48 \mathrm{~h}$ with the indicated concentrations $(0 \sim 125 \mathrm{mg} / \mathrm{ml})$ of $5-\mathrm{FU},(0 \sim 12.5 \mathrm{mg} / \mathrm{ml})$ of abraxane and $(0 \sim 12.5 \mathrm{mg} / \mathrm{ml})$ of cisplatine in the presence of $0.08,0.16,0.31,0.63$ or $1.25 \mathrm{mg} / \mathrm{ml}$ of Chi-NP and, then, the viable cell number was determined by the MTT method. Each value represents the mean of 6 determinations. Upper column in two experiments (Exp. 1 and Exp. 2) shows the dose-response curve of cell viability. Lower column represents the combination index (CI), calculated as described in Materials and Methods.
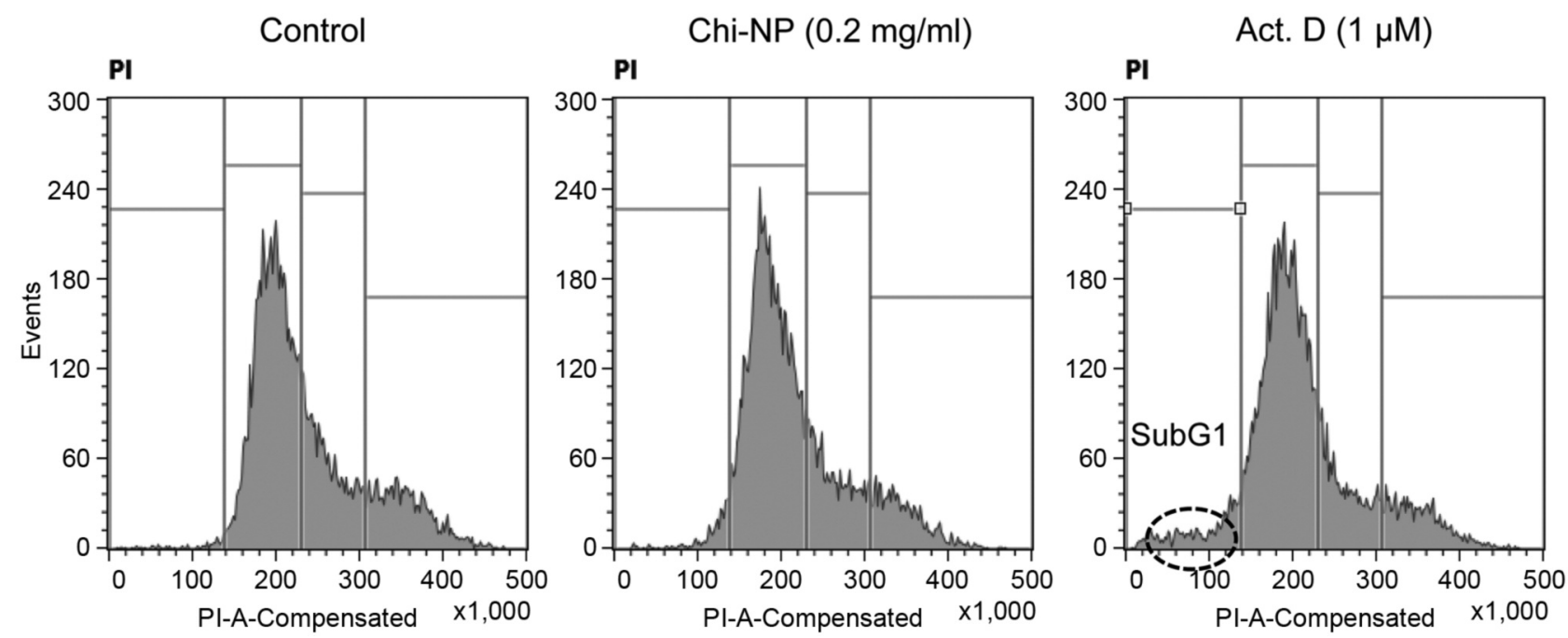

Figure 8. Effect of Chi-NP on cell-cycle analysis in HSC-2 cells. Cells were incubated for $24 \mathrm{~h}$ without (control) or with Chi-NP (0.2 mg/ml) or actinomycin $D(1 \mu M)$, and then subjected to cell cycle analysis. 

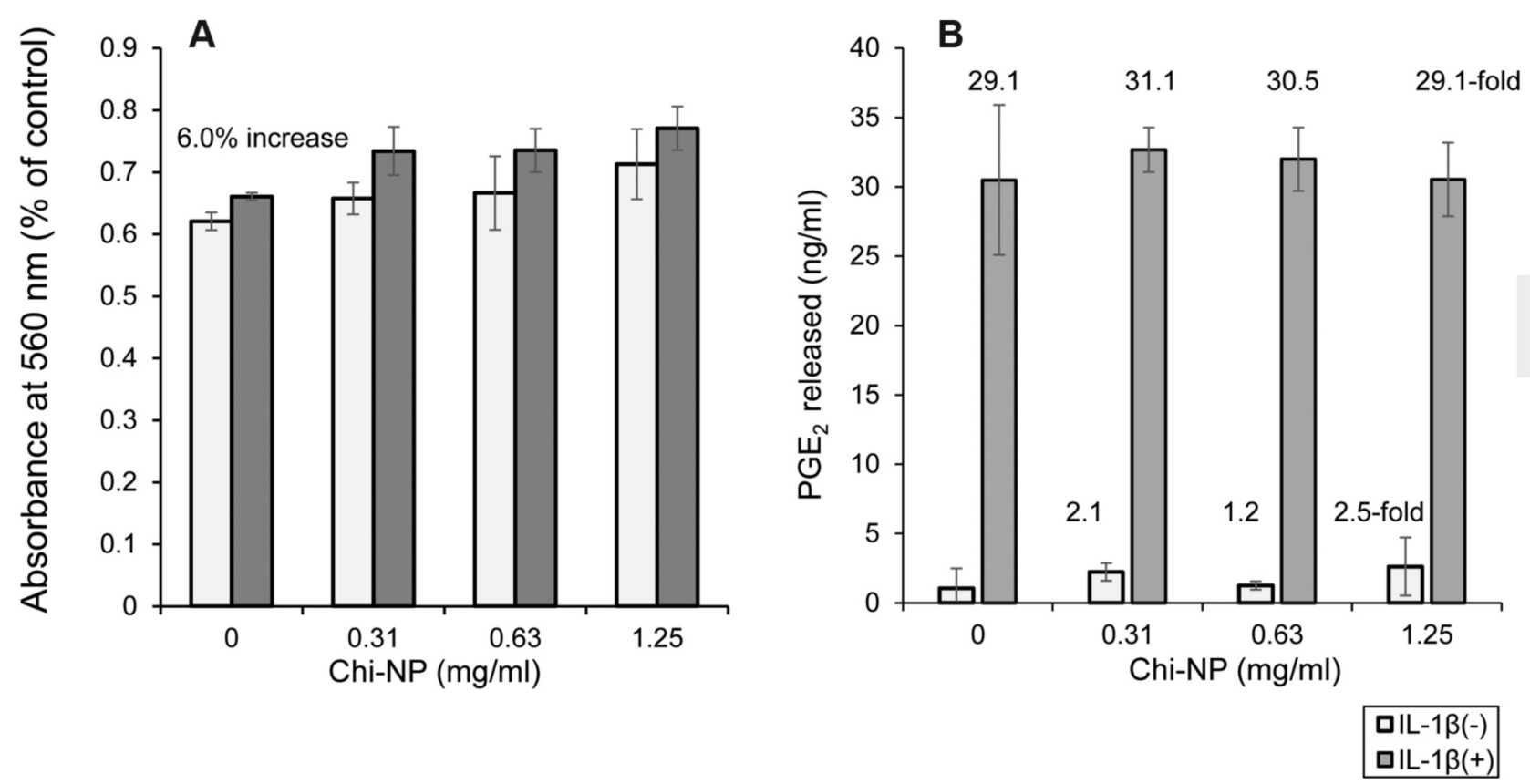

Figure 9. Effect of Chi-NP on IL-1 $\beta$-stimulated of PGE production in HGFs. HGFs (18 PDL) were incubated for $48 \mathrm{~h}$ with the indicated concentrations of Chi-NP in the presence or absence of $I L-1 \beta(3 \mathrm{ng} / \mathrm{ml})$. The extracellular concentration of PGE 2 was determined by ELISA. Each value represents mean $\pm S . D$. of 3 determinations.

NP showed some antagonistic and protective effects against the anticancer drugs $(\mathrm{CI}>1)$ (Figure 7). Cell sorter analysis demonstrated that control and Chi-NP-treated cells did not induce accumulation of cells at the subG1 phase of the cell cycle, whereas actinomycin D (positive control) increased the number of cells in the subG1 phase by $7.6 \%$ (Figure 8 ).

Pro-inflammatory action. IL-1 $\beta(3 \mathrm{ng} / \mathrm{ml})$ stimulated the growth of HGF cells approximately by $6.0 \%$ (Figure 9A) and enhanced $\mathrm{PGE}_{2}$ production by $29.1 \%$ (Figure $9 \mathrm{~B}$ ), in consistent with our previous finding (19). Addition of $0.31,0.63$ and $1.25 \mathrm{mg} / \mathrm{ml}$ Chi-NP also increased $\mathrm{PGE}_{2}$ production by $2.1,1.2$ and 2.5fold, respectively, and a combination of these concentrations of Chi-NP and IL-1 $\beta$ (3 ng/ml) produced 29.1, 31.1, 30.5 and 29.1-fold increase in $\mathrm{PGE}_{2}$ production, respectively (Figure 9). These results indicate that Chi-NP has very little effect on both spontaneous and IL-1 $\beta$-induced $\mathrm{PGE}_{2}$ production by HGFs.

Effect on X-ray-induced cytotoxicity. When HSC-2 cells were incubated with $0.16,0.31,0.63,1.25$ and $2.5 \mathrm{mg} / \mathrm{ml}$ Chi-NP, the absorbance at $560 \mathrm{~nm}$ was increased by $3.1,7.2,30.1,46.8$ and 91.9\% as compared with the control (no Chi-NP treatment), respectively (Figure 10). X-Ray irradiation (900 mGy) reduced the absorbance values by $12.9,8.1,8.1,8.5,10.9$ and $10.8 \%$, respectively (Figure 10). This indicates that Chi-NP could not completely rescue the X-ray-induced cell damage.

\section{Discussion}

The present study demonstrated that chitosan FL-80 and chitosan nanofiber slightly stimulated the growth of HSC-2 cells at lower concentrations $(0.01 \sim 0.63 \mathrm{mg} / \mathrm{ml})$ whereas chitosan FM-80, FH-80 and 100 were slightly inhibitory. Chitosan samples (FL-80, FM-80, FH-80 and 100) and chitosan nanofibers at concentrations higher than 1.25 or $0.63 \mathrm{mg} / \mathrm{ml}$ were cytotoxic (Figure 2). Growth inhibition by higher concentrations of chitosan nanofiber is possibly due to its acidity, since the stock solution was dissolved in $0.5 \%$ acetic acid. Growth inhibition by other 4 chitosan samples, dissolved in isotonic pH 5 buffer, was much milder.

We found that chitosan FL-80 binding to HSC-2 cells at pH 5 was negligible (Figure 3D) whereas FL-80-magnetic nanoparticles attached to the cells (Figure 3E). However, nanofiber binding to the cells was much prominent, even exceeding that of nanofiber magnetic nanoparticles (Figure $3 F$ ). From the calibration curve (Figure 3D), we estimated that nearly $22 \%$ of the initially added LH-80 was bound to the cells after $10 \mathrm{~min}$, as is shown by the following calculation: \%Bound $=\{[0.084-0.038$ (background) $] /$ $[0.1046 \times 2)]\} \times 100=22 \%$ (Figure $3 \mathrm{E}$ ). If the calibration curve of LH-80 (Figure 3D) is assumed to be applicable to that for nanofiber, nearly $125 \%$ of the initially added nanofibers should be bound to the cells, as shown by the following 


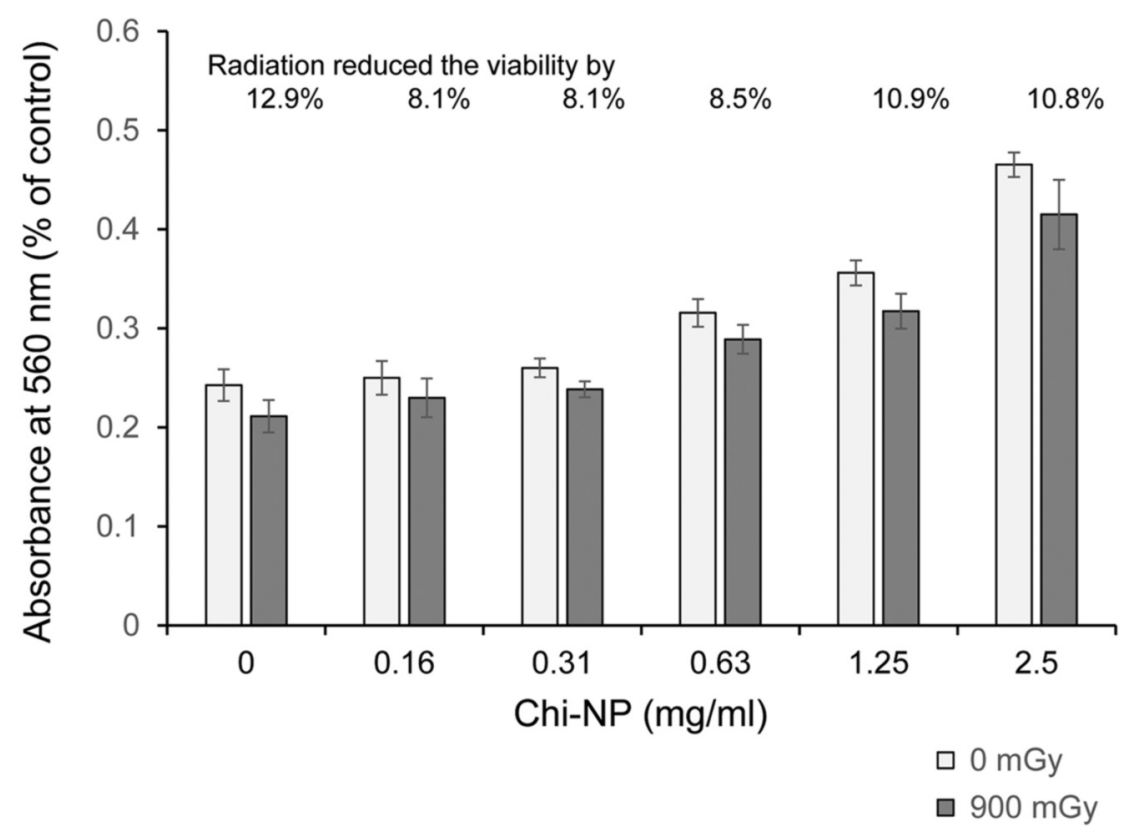

Figure 10. Effect of Chi-NP on the X-ray (900 mGy)-induced cytotoxicity in HSC-2 cells. After changing the medium with fresh DMEM supplemented with $10 \%$ FBS and the indicated concentrations of Chi-NP, HSC-2 cells were exposed to X-ray irradiation at $900 \mathrm{mGy}$ (=28.12 mGy 32 times), and then incubated for $48 \mathrm{~h}$ to determine the viable cell number (expressed as absorbance at $560 \mathrm{~nm}$ ) by the MTT method. Each value represents mean \pm S.D. of 5 determinations.

calculation: \% Bound $=\{[0.298-0.037 \quad$ (background) $] /$ $[0.1046 \times 2]\} \times 100=125 \%$ (Figure $3 \mathrm{~F})$. This demonstrates that the binding of LH-80 and especially of nanofibers was rapid and complete. Higher affinity of nanofiber may have applications for efficient drug delivery.

Chitosan magnetic nanoparticles (Chi-NP), prepared by mixing chitosan FL-80 and magnetic nanoparticles, easily form aggregates in contact with the culture medium (Figure 4). When HSC-2 cells were incubated with increasing concentrations of Chi-NP, the absorbance at $560 \mathrm{~nm}$ was increased. The increase of the absorbance at $560 \mathrm{~nm}$ may arise from the attachment of Chi-NP to the cells and the interaction with the MTT reagent (Figure 5). It may be necessary to set up the conditions that prevent the aggregation or reduce the size to be applicable to living organisms utilizing biomaterial techniques.

Our data suggest that Chi-NP have no effect on apoptosis (Figure 8), cytotoxicity of anticancer drugs (5-FU, abraxane and cisplatin) (Figure 7) and X-ray (Figure 10), or induction of basal and IL-1 $\beta$-induced $\mathrm{PGE}_{2}$ production by human gingival fibroblasts (Figure 9). This may be due to the formation of aggregation, that should inhibit the intracellular uptake, since we have previously found that cell-permeable $\mathrm{TiO}_{2}$ nanoparticles enhanced $\mathrm{PGE}_{2}$ and COX-2 expression in HGFs (19).

$\mathrm{X}$-Ray irradiation at $900 \mathrm{mGy}$ reduced the viability of HSC-2 cells (12.9\%), but to nearly one-third of that observed in NGF-treated rat neuronal PC12 cells (30 40\%) (18). Chi-
NP at wide range of concentrations $(0.16 \sim 2.5 \%)$, failed to protect the cells from X-ray-induced damage (Figure 10).

Chitosan may induce quite different or more complex effects in in vivo. It has been recently reported that orally administered chitosan show antifibrotic effects in a rat model of bleomycin-induced pulmonary fibrosis (20). It should be tested whether such favorable effect may be induced by binding of chitosan to the oral tissue, thus inhibiting the production of pro-inflammatory cytokines.

In conclusion, we found that chitosan magnetic nanoparticles were biologically inert, indicating that they can be safely used as a scaffold for drug delivery. The tumortargeting magnetic property of Chi-NP may further augment the tumor-specificity of anticancer drugs.

\section{Conflicts of Interest}

The Authors wish to confirm that there are no known conflicts of interest associated with this publication and there has been no significant financial support for this work that could have influenced its outcome.

\section{Authors' Contributions}

A.D.P-G. prepared nanoparticles and performed the binding assay, cytotoxicity assay, and cell cycle analysis with the help with H.S., Y.I. and K.B. Y.K. performed the TEM analysis. Y.N., Y.H. and H.N. 
performed the SEM analysis. G.N., Y.K-O., A.S., T.N. and D.U performed the $\mathrm{X}$-ray irradiation and data evaluation. S.N., S.I. and M.Y provided the chitosans and information of their physicochemical properties. A.D.P-G., H.S., H.N., S.Y., O.A., K.K. and R.G-C. organized the research and wrote the manuscript.

\section{Acknowledgements}

This work was partially supported by Meikai University Research Fund B.

\section{References}

1 Younes I and Rinaudo M: Chitin and chitosan preparation from marine sources. Structure, properties and applications. Mar Drugs 13(3): 1133-1174, 2015. PMID: 25738328. DOI: 10.3390/ md13031133

2 Ducret M, Montembault A, Josse J, Pasdeloup M, Celle A, Benchrih R, Mallein-Gerin F, Alliot-Licht B, David L and Farges JC: Design and characterization of a chitosan-enriched fibrin hydrogel for human dental pulp regeneration. Dent Mater 35(4): 523-533, 2019. PMID: 30712823. DOI: 10.1016/j.dental. 2019.01.018

3 Aguilar A, Zein N, Harmouch E, Hafdi B, Bornert F, Offner D, Clauss F, Fioretti F, Huck O, Benkirane-Jessel N and Hua G: Application of chitosan in bone and dental engineering. Molecules 24(16), 2019. PMID: 31431001. DOI: 10.3390/ molecules 24163009

4 Husain S, Al-Samadani KH, Najeeb S, Zafar MS, Khurshid Z, Zohaib S and Qasim SB: Chitosan biomaterials for current and potential dental applications. Materials (Basel) 10(6), 2017. PMID: 28772963. DOI: 10.3390/ma10060602

5 Ahsan SM, Thomas M, Reddy KK, Sooraparaju SG, Asthana A and Bhatnagar I: Chitosan as biomaterial in drug delivery and tissue engineering. Int J Biol Macromol 110: 97-109, 2018. PMID: 28866015. DOI: 10.1016/j.ijbiomac.2017.08.140

6 Assa F, Jafarizadeh-Malmiri H, Ajamein H, Vaghari H, Anarjan $\mathrm{N}$, Ahmadi $\mathrm{O}$ and Berenjian A: Chitosan magnetic nanoparticles for drug delivery systems. Crit Rev Biotechnol 37(4): 492-509, 2017. PMID: 27248312. DOI: 10.1080/07388551.2016.1185389

7 Ahmed TA and Aljaeid BM: Preparation, characterization, and potential application of chitosan, chitosan derivatives, and chitosan metal nanoparticles in pharmaceutical drug delivery. Drug Des Devel Ther 10: 483-507, 2016. PMID: 26869768. DOI: $10.2147 /$ DDDT.S99651

8 Kamath PR and Sunil D: Nano-chitosan particles in anticancer drug delivery: An up-to-date review. Mini Rev Med Chem 17(15): 1457-1487, 2017. PMID: 28245780. DOI: 10.2174/ 1389557517666170228105731

9 Prabaharan M: Chitosan-based nanoparticles for tumor-targeted drug delivery. Int J Biol Macromol 72: 1313-1322, 2015. PMID: 25450550. DOI: 10.1016/j.ijbiomac.2014.10.052

10 Landriscina A, Rosen $\mathrm{J}$ and Friedman AJ: Biodegradable chitosan nanoparticles in drug delivery for infectious disease. Nanomedicine (Lond) 10(10): 1609-1619, 2015. PMID: 26008195. DOI: $10.2217 / \mathrm{nnm} .15 .7$
11 Rajitha P, Gopinath D, Biswas R, Sabitha M and Jayakumar R: Chitosan nanoparticles in drug therapy of infectious and inflammatory diseases. Expert Opin Drug Deliv 13(8): 1177-1194, 2016. PMID: 27087148. DOI: 10.1080/17425247.2016.1178232

12 Unsoy G, Yalcin S, Khodadust R, Mutlu P, Onguru O and Gunduz U: Chitosan magnetic nanoparticles for ph responsive bortezomib release in cancer therapy. Biomed Pharmacother 68(5): 641-648, 2014. PMID: 24880680. DOI: 10.1016/j.biopha. 2014.04.003

13 Ghadi A, Tabandeh F, Mahjoub S, Mohsenifar A, Roshan FT and Alavije RS: Fabrication and characterization of core-shell magnetic chitosan nanoparticles as a novel carrier for immobilization of burkholderia cepacia lipase. J Oleo Sci 64(4): 423-430, 2015. PMID: 25833452. DOI: 10.5650/jos.ess14236

14 Shan X, Xu T, Liu Z, Hu X, Zhang YD and Wang B: Safety and toxicology of the intravenous administration of ang2sirna plasmid chitosan magnetic nanoparticles. Mol Med Rep 15(2): 736-742, 2017. PMID: 28035391. DOI: $10.3892 / \mathrm{mmr} .2016 .6090$

15 Iijima Y, Bandow K, Sano M, Hino S, Kaneko T, Horie N and Sakagami H: In vitro assessment of antitumor potential and combination effect of classical and molecular-targeted anticancer drugs. Anticancer Res 39(12): 6673-6684, 2019. PMID: 31810932. DOI: 10.21873 /anticanres.13882

16 Sakagami H, Sugimoto M, Kanda Y, Murakami Y, Amano O, Saitoh J and Kochi A: Changes in metabolic profiles of human oral cells by benzylidene ascorbates and eugenol. Medicines (Basel) 5(4), 2018. PMID: 30384403. DOI: 10.3390/ medicines5040116

17 Sugimori N, Espinoza JL, Trung LQ, Takami A, Kondo Y, An DT, Sasaki M, Wakayama T and Nakao S: Paraptosis cell death induction by the thiamine analog benfotiamine in leukemia cells. PLoS One 10(4): e0120709, 2015. PMID: 25849583. DOI: 10.1371/journal.pone.0120709

18 Nakaya G, Sakagami H, Koga-Ogawa Y, Shiroto A, Nobesawa T, Ueda D, Nakatani S, Kobata K, Iijima Y, Tone S, DavidGonzalez A, Garcia-Contreras R, Tomomura M, Kito S, Tamura $\mathrm{N}$ and Takeshima $\mathrm{H}$ : Augmentation of neurotoxicity of anticancer drugs by x-ray irradiation. In Vivo 34(3): 1009-1016, 2020. DOI: 10.21873 /invivo.11869

19 Garcia-Contreras R, Sugimoto M, Umemura N, Kaneko M, Hatakeyama Y, Soga T, Tomita M, Scougall-Vilchis RJ, Contreras-Bulnes R, Nakajima H and Sakagami H: Alteration of metabolomic profiles by titanium dioxide nanoparticles in human gingivitis model. Biomaterials 57: 33-40, 2015. PMID: 25913073. DOI: 10.1016/j.biomaterials.2015.03.059

20 Kim YS Li Q, Youn HY and Kim DY: Oral administration of chitosan attenuates bleomycin-induced pulmonary fibrosis in rats. In Vivo 33(5): 1455-1461, 2019. PMID: 31471392. DOI: 10.21873/invivo. 11624

Received March 30, 2020

Revised April 7, 2020

Accepted April 8, 2020 